\title{
Two new species of Beraba Martins, 1997 and new geographical records of Eburiini (Coleoptera, Cerambycidae)
}

\author{
Kimberly García', Juan Pablo Botero², Neis José Martínez' \\ I Semillero de investigación Artrópodos NEOPTERA del Caribe Colombiano. Programa de Biología, Facultad \\ de Ciencias Básicas, Universidad del Atlántico, Carrera 30 \# 8-49 Puerto Colombia, Atlántico, Colombia \\ 2 Laboratório de Coleoptera, Museo de Zoologia, Universidade de São Paulo, Av. Nazaré, 481 - Ipiranga, São \\ Paulo, Brazil \\ Corresponding author: Kimberly García L. (kimberly.pg@gmail.com) \\ Academic editor: F. Vitali | Received 8 November 2018 | Accepted 19 December 2018 | Published 5 March 2019 \\ http://zoobank.org/5FA0015D-4A0A-4EBB-B8E7-7A09EB967DDD \\ Citation: García K, Botero JP, Martínez NJ (2019) Two new species of Beraba Martins, 1997 and new geographical \\ records of Eburiini (Coleoptera, Cerambycidae). ZooKeys 827: 125-138. https://doi.org/10.3897/zookeys.827.31469
}

\begin{abstract}
Two new species of Beraba from Colombia (Bolívar) are described: Beraba anae sp. n. and Beraba angeli sp. $\mathbf{n}$. The most recent key to species of the genus was modified to incorporate the new species. The male of Beraba limpida Martins, 1997 is described and illustrated for the first time. Moreover, the geographical distribution of 12 species of Eburiini is expanded.
\end{abstract}

\section{Keywords}

Atlántico, Bolívar, Caribbean, Eburodacrys, taxonomy, longhorn beetle, tropical dry forest

\section{Introduction}

The tribe Eburiini is currently composed of 24 genera and 268 species, all of them with a geographical distribution restricted to North, Central (including the Caribbean) and South America (Botero and Monné 2018). 
The genus Beraba Martins, 1997 was described to gather together the species described initially in Eburia Lacordaire, 1830 having a bright aspect, antennomere III longer than IV, and femora with spines restricted to the inner margin. Later, Galileo and Martins (2000) transferred Eburodacrys cheilaria Martins, 1967 to the genus. Currently, the genus includes 18 species distributed from Panama to South America. Three of these species - B. inermis Martins \& Galileo, 2002, B. marica Galileo \& Martins, 2000 and B. piriana Martins, 1997 - are known to occur in Colombia (Botero 2015; Tavakilian and Chevillotte 2018).

In this work two new species of Beraba are described, $B$. anae sp. n. and $B$. angeli sp. n.; the male of B. limpida Martins, 1997 is redescribed and the geographical distribution is expanded for 12 species. The key proposed by Botero (2015) for Beraba is modified to include the new species.

\section{Material and methods}

The material examined was obtained in Colombia, from the tropical dry forest in the Reserva La Flecha (RLF), Bolívar and the Reserva Campesina la Montaña (RCM), Atlántico. These locations were sampled from February to May 2018 by using a UV light trap, white light trap, manual capture, and the sampling was supplemented by visits to entomological collections.

The material currently resides in the following institutions, which are subsequently referred to by their acronyms:

ANDES-E Colección Entomológica, Museo de Historia Natural, Universidad de Los Andes, Bogotá, Colombia (Yiselle Patricia Cano);

IAVH Instituto de Investigaciones de Recursos Biológicos "Alexander von Humboldt", Villa de Leyva, Colombia (Jhon Cesar Neita);

MPUJ Pontificia Universidad Javeriana, Bogotá, Colombia (Igor Dimitri Forero, Giovanny Fagua);

MZSP Museu de Zoologia, Universidade de São Paulo, São Paulo, Brazil (Sônia Casari, Antonio Santos-Silva);

UARC Universidad del Atlántico, Puerto Colombia, Colombia (Neis José Martínez).

Photographs were taken with a Canon EOS Rebel T3i DSLR camera, Canon MP-E 65mm f/2.8 1-5× macro lens, controlled by Zerene Stacker focus stacking software. Measurements were taken in " $\mathrm{mm}$ " using a measuring ocular Hensoldt/Wetzlar - Mess 10 in the Leica MZ6 stereomicroscope, also used in the study of the specimens. References and geographical distributions were ascertained in Martínez (2000), Monné (2018) and Tavakilian and Chevillotte (2018) catalogs. 


\section{Results}

Cerambycidae Latreille, 1802

Cerambycinae Latreille, 1802

Eburiini Blanchard, 1845

\section{Beraba anae sp. n.}

http://zoobank.org/8E564587-C14F-4F52-8D96-14D8AB7CDA29

Figs $1-5$

Type material. Holotype female from Colombia, Bolívar: San Jacinto (Reserva La Flecha, $324 \mathrm{~m}, 09^{\circ} 51^{\prime} 12.4^{\prime \prime} \mathrm{N}, 75^{\circ} 10^{\prime} 41.4 " \mathrm{~W}$, tropical dry forest), 15.IV.2018, García, K coll., UV light trap, MPUJ_ENT 0064073 (MPUJ). Paratype, male from Colombia, Bolívar: San Jacinto (Reserva La Flecha, 324 m, 0951'12.4"N, 75¹0'41.4"W, tropical dry forest), 15.IV.2018, García, K coll., white light trap (UARC).

Diagnosis. Surface of pronotum smooth with pronotal tubercles of same color as remainder; eburneous callosities subrounded, posterior ones placed at same level and subequal in size; elytral costae absent; meso- and metafemora with a long spine; elytral apex truncate, with spine at outer margin.

Description. Female. Integument brownish orange. Apex of lateral tubercles of prothorax darker. Antennae, femora and tibiae slightly lighter. Scutellum brown. Posterior region of anterior eburneous callosity and, anterior and posterior region of posterior eburneous callosities black.

Body covered with long, erect sparse setae, denser at inner face of protibiae, protarsomeres and basal antennomeres.

Head. Upper ocular lobes well separated, distance between them about 4 times width of upper lobe. Antennae exceeding elytral apices at antennomere VIII. Antennal formula (ratio) based on length of antennomere III: scape $=0.73$; pedicel $=0.15$; IV $=0.84 ; \mathrm{V}=0.82 ; \mathrm{VI}=0.82 ; \mathrm{VII}=0.82 ; \mathrm{VIII}=0.80 ; \mathrm{IX}=0.75 ; \mathrm{X}=0.64 ; \mathrm{XI}=0.76$.

Thorax. Prothorax (including lateral tubercles) slightly longer than wide. Sides of prothorax with tubercles distinct, acute at apex; antemedian gibbosity slightly elevated. Surface of pronotum smooth, with sparse shallow punctures, and a few sparse long setae arising from each puncture. Pronotum with two anterior tubercles weakly elevated, rounded at apex, and a centro-longitudinal slightly elevated gibbosity. Prosternum smooth with a few sparse long erect setae. Prosternal process expanded at apex, width at narrowest point equal to one fifth of procoxal cavity width. Prosternal process, meso and metaventrite covered with dense goldish pubescence, denser and longer at lateral regions. Elytra about three times longer than prothorax; surface with moderately dense, coarse punctures on anterior half, finer and shallow toward apex. Each elytron with 3 eburneous callosities: one anterior, elliptical; two posterior slightly elongated, subequal, about one fifth of elytral length, not distinctly separated, external starting 

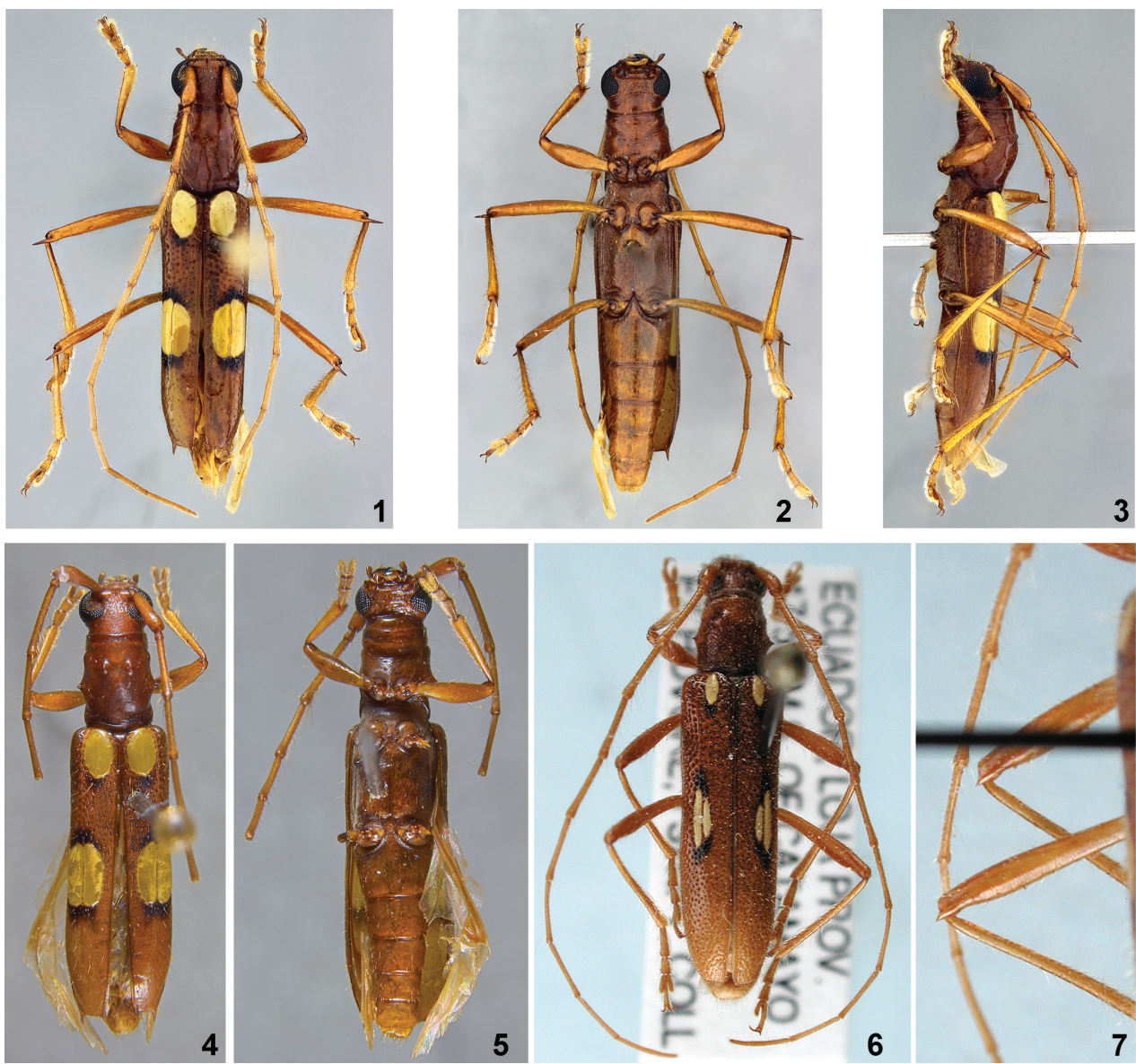

Figures I-7. I-5 Beraba anae sp. nov.: I dorsal view, holotype female $\mathbf{2}$ ventral view, holotype female 3 lateral view, holotype female 4 dorsal view, paratype male 5 ventral view, paratype male 6-7 Beraba iuba Martins, 1997.

slightly ahead of inner one; elytral costae absent. Apex of elytra truncate, with external spine, and a very small sutural spicule.

Abdomen. Ventrites finely, sparsely punctate, sparser on median region; with a few long, sparse whitish setae. Apex of ventrite V slightly emarginate.

Variability. In the paratype (male), the posterior eburneous callosities start at the same point. The ventrite $\mathrm{V}$ is shorter and square-shaped in males, with apex truncate.

Measurements. Holotype female: Total length, 10.6; prothorax length, 2.4; prothorax width at its widest point, 2.1; elytral length, 7.0; humeral width, 2.4. Paratype male: Total length, 11.3; prothorax length, 2.3; prothorax width at its widest point, 2.0; elytral length, 7.0; humeral width, 2.2.

Etymology. The species epithet is in honor of Ana López Guerrero, mother of the first author, in appreciation of her love and support through all my life, the reason for all of my achievements. 
Discussion. Beraba anae sp. $\mathrm{n}$. is similar to B. iuba Martins, 1997 (Figs 6-7) and B. moema Martins, 1997 in having only one elliptical eburneous callosity at the anterior region of each elytron, tubercles of the pronotum concolor with remaining surface and posterior eburneous callosities starting at the same level. Beraba anae sp. n. differs from $B . i u b a$ in having the posterior eburneous callosities elliptical in shape and subequal in size (in $B$. iuba, the posterior callosities are more elongated and the inner one is shorter than the external one), spined elytral apex (unarmed in $B$. iuba), and in the long mesoand metafemoral spines, longer than the scape (shorter than the scape in B. iuba). Beraba anae sp. n. differs from $B$. moema in the surface of the pronotum smooth, eburneous callosities narrowed and subrounded, posterior callosities with similar size, elytral costae absent, and elytral apex truncate. In B. moema, the surface of pronotum is coarsely punctuate, eburneous callosities are narrowed with the posteroexternal at least twice length of the internal, the elytral costae are visible, and the elytral apex is obliquely truncate.

\section{Beraba angeli sp. $\mathrm{n}$.}

http://zoobank.org/596B3878-6A51-4F68-B659-1CAB4D72B47E

Figs $8-11$

Type material. Holotype male from Colombia, Bolívar: San Jacinto (Reserva La Flecha, $324 \mathrm{~m}, 09^{\circ} 51^{\prime} 12.4^{\prime \prime} \mathrm{N}, 75^{\circ} 10^{\prime} 41.4 " \mathrm{~W}$, tropical dry forest), 16.IV.2018, García, K. coll., white light trap, MPUJ_ENT 0064074 (MPUJ). Paratype, male from Colombia, Bolívar: San Jacinto (Reserva La Flecha, $324 \mathrm{~m}, 09^{\circ} 51^{\prime} 12.4^{\prime \prime N}, 75^{\circ} 10^{\prime} 41.4 " \mathrm{~W}$, tropical dry forest), 15.IV.2018, García, K. coll., UV light trap (UARC).

Diagnosis. Surface of pronotum with wrinkles; pronotal tubercles black and wellelevated; males with sexual punctation on prosternum; femoral spines of same color as remainder; eburneous callosities with similar size; elytral apex with external spine.

Description. Male. Integument brownish orange, legs slightly lighter. Pronotal tubercles, posterior region of anterior eburneous callosity, and anterior and posterior region of posterior eburneous callosities black.

Body covered with long, erect and sparse yellowish setae.

Head. Upper ocular lobes well separated, distance between them about 3 times width of upper lobe. Antennae exceeding elytral apices at antennomere VIII. Antennal formula (ratio) based on length of antennomere III: scape $=0.57$; pedicel $=0.11$;V $=0.83 ; \mathrm{V}=0.83 ; \mathrm{VI}=0.83 ; \mathrm{VII}=0.80 ; \mathrm{VIII}=0.74 ; \mathrm{IX}=0.69 ; \mathrm{X}=0.63 ; \mathrm{XI}=0.80$.

Thorax. Prothorax (including lateral tubercles) longer than wide. Sides of prothorax with tubercles distinct and acute at apex. Surface of pronotum coarsely punctate with transverse wrinkles, more distinct on posterior half, with a few long sparse whitish setae. Pronotum with two anterior tubercles well elevated, rounded at apex, and a centro-longitudinal slightly elevated gibbosity. Prosternum with transverse sulcus, glabrous, with long yellowish setae, finely transversely striate, coarsely punctate on posterior half, with two well-defined areas of sexual punctation. Prosternal process expanded at apex, width at narrowest point equal to one fourth of procoxal cavity width. Pros- 


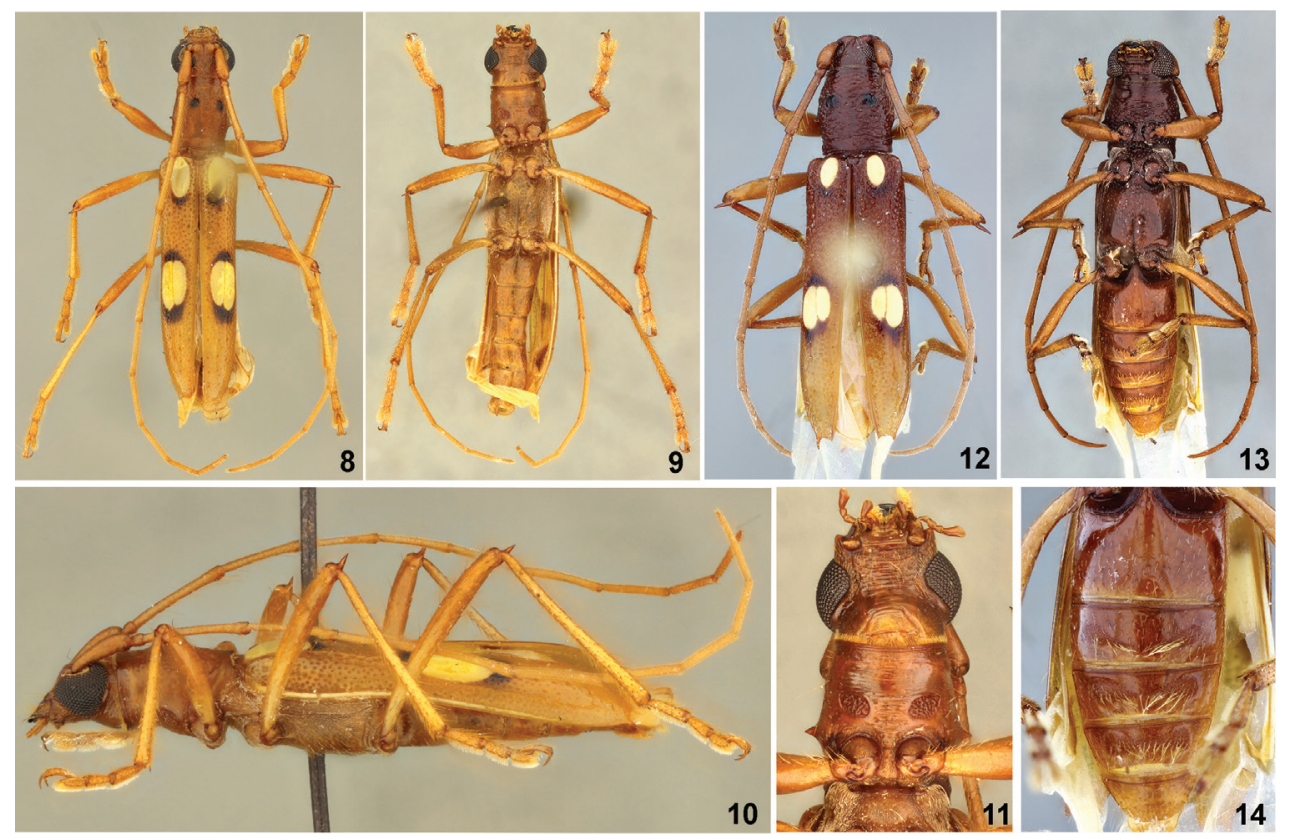

Figures 8-I4. 8-I I Beraba angeli sp. nov., holotype, male: 8 dorsal view 9 ventral view 10 lateral view I I detail of prosternum. I 2-I 4 Beraba marica Martins \& Galileo, 1999: I 2 dorsal view I 3 ventral view 14 detail of ventrites.

ternal process, meso- and metaventrite covered with dense golden pubescence, denser and longer laterally. Elytra about three times longer than prothorax; surface with moderately dense, coarse punctures on anterior half, finer and shallower toward apex. Each elytron with 3 subrounded eburneous callosities: one anterior; two posterior subfused, subequal, starting at same level, external slightly curved. Elytral costae absent. Apex of elytra truncate, with external spine and dentiform projection at sutural angle.

Abdomen. Ventrites finely sparsely punctate, sparser on median region; with a few moderately long, sparse yellowish setae. Apex of ventrite $V$ truncate.

Measurements. Holotype male: total length, 9.5; prothorax length, 1.9; prothorax width at its widest point, 1.7; elytral length, 6.3; humeral width, 2.0. Paratype male: total length, 11.9; prothorax length, 2.5; prothorax width at its widest point, 2.5; elytral length, 8.1; humeral width: 2.7.

Etymology. The species epithet is in honor of Angel García Hernandez, father of the first author, as a thank you for all the support, love and happiness he has given to me.

Discussion. Beraba angeli sp. n. is similar to B. marica Galileo \& Martins, 1999 (Figs 12-14) and B. inermis Martins \& Galileo, 2002 in having only one elliptical eburneous callosity on the anterior region of each elytron, tubercles of the pronotum black, and surface of the pronotum only with wrinkles or with wrinkles and some interspersed punctures. Beraba angeli sp. $\mathrm{n}$. differs of B. marica in having the pronotal tubercles distinctly elevated, prosternum with areas of sexual punctation (Fig. 11), and the male ventrites not modified (in B. marica the tubercles are slightly elevated, proster- 
num does not show sexual punctation, and ventrites II-IV show depressed areas with long yellowish setae on the posterior margin in males, as in Fig. 14). Beraba angeli sp. n. differs of $B$. inermis in the posterior eburneous callosities of similar size, and apex of the elytra with an external spine (in $B$. inermis, the posteroexternal eburneous callosities is, at least, twice the length of internal, and the external apex of the elytra is unarmed).

According to the most recent key to species of Beraba (Botero, 2015), the two new species can be inserted as follows:

7(4) Tubercles of pronotum of same color as remainder of pronotum...............8

- Tubercles of pronotum black (contrasting in color from remainder of pronotum)

8(7) Posteroexternal eburneous callosity of elytra placed at beginning of apical third and distant internal callosity. Brazil (Rio de Janeiro)

B. angusticollis (Zajciw, 1961)

- $\quad$ Posterior eburneous callosities of elytra placed at same level

9(8) Meso- and metafemora with short inner spine, shorter than length of scape; elytral apex unarmed (Figs 6-7). Colombia (Bolívar), Ecuador (Pichincha) .....

B. iuba Martins, 1997

- $\quad$ Meso- and metafemora with long inner spine, longer than length of scape; elytral apex with spines

10(9) Surface of pronotum coarsely punctate; eburneous callosities narrowed, posteroexternal eburneous callosity at least twice length of internal; elytral costae visible; elytral apex obliquely truncate. Ecuador (El Oro, Guayas, Manabi).....

B. moema Martins, 1997

- $\quad$ Surface of pronotum smooth; eburneous callosities wider, subrounded; posterior eburneous callosities with similar size; elytral costae absent; elytral apex truncate (Figs 1-5). Colombia (Bolívar)

B. anae sp. $\mathrm{n}$.

11(7) Apex and spines of femora of same color as remainder ...........................12

- $\quad$ Apex and spines of femora black, contrasting with adjacent color .............16

12(11) Surface of pronotum only with wrinkles or with wrinkles and some interspersed punctures............................................................... 13

- $\quad$ Surface of pronotum only with punctures, without wrinkles....................15

13(12) Posteroexternal eburneous callosities at least twice length of internal; external apex of elytra unarmed. Colombia (Amazonas, Bolívar, Cundinamarca, Valle del Cauca) ........................................ B. inermis Martins \& Galileo, 2002

- $\quad$ Posterior eburneous callosities with similar size; apex of elytra with external spine.......................................................................... 14

14(13) Pronotal tubercles slightly elevated; prosternum without sexual punctation; ventrites II-IV of males with depressed areas and with long yellowish setae on posterior margin of those areas (Figs 12-14). Colombia (Atlántico, Bolívar, Magdalena, Santander)

B. marica Galileo \& Martins, 1999

- $\quad$ Pronotal tubercles distinctly elevated; prosternum with areas of sexual punctation (Fig. 11); ventrites of males not modified (Figs 8-11). Colombia (Bolívar) 
15(12) Basal eburneous callosities narrowed and elongated; elytral costae visible behind posterior callosities. Bolivia (Santa Cruz) ....... B. tate Galileo \& Martins, 2010

- $\quad$ Basal eburneous callosities short and subrounded; without elytral costae visible behind posterior callosities (Figs 15-19). Colombia (Bolívar), Venezuela.

B. limpida Martins, 1997

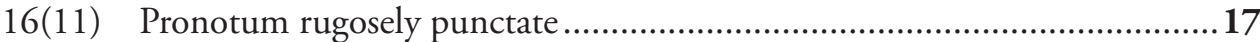

- $\quad$ Pronotum smooth or only with microsculpture ......................................19

17(16) Scape black or darker than flagellomeres; prothorax subparallel-sided; eburneous callosities elongate and thin. Brazil (Goiás, Maranhão, Mato Grosso, Piauí).

B. decora (Zajciw, 1961)

- $\quad$ Scape with same color as flagellomeres; prothorax curved at sides or narrowed toward anterior margin; eburneous callosities elliptical 18

18(17) Lateral tubercle of prothorax small; posterior eburneous callosities starting anteriorly at same level; apex of elytra with black area. French Guiana...........

B. odettae Martins \& Galileo, 2008

- $\quad$ Lateral tubercle of prothorax long and acute; posteroexternal eburneous callosity starting behind internal one; apex of elytra without black area. Peru....

B. spinosa (Zajciw, 1967)

19(16) Prothorax longer than wide, anterior region of epipleura without projection, metafemora exceeding elytral apex. Brazil (Amazonas), French Guiana

B. cauera Galileo \& Martins, 1999

- $\quad$ Prothorax as long as wide; anterior region of epipleura with projection, metafemora not exceeding elytral apex. Brazil (Mato Grosso do Sul), Bolivia (Cochabamba, Santa Cruz), Paraguay.....

B. cheilaria (Martins, 1967)

\section{Beraba limpida Martins, 1997}

Figs 15-19

Material examined. Colombia, Bolívar: San Jacinto (Reserva La Flecha, 0951'12.4"N, 75¹0'41.4"W, tropical dry forest), 1 male, 27.IV.2017, I. Mendoza coll., light trap (UARC). Venezuela, Aragua: El Limón, 1 male, 23.V.1997, F. Fernandez coll., mercury light (MZSP).

Redescription. Male. Integument dorsally orange, brownish orange ventrally. Posterior region of head, pronotum, lateral tubercles of prothorax and legs brownish orange. Elytra and scutellum yellowish orange. Pronotal tubercles, posterior region of anterior eburneous callosities and, region around posterior eburneous callosities black.

Body covered with long, erect, sparse setae, denser on inner surface of tibiae, tarsomeres and basal antennomeres.

Head. Posterior region of head, scape and basal antennomeres with dense punctuation. Distance between upper lobes about three times width of upper lobe. Antennae exceeding elytral apices at apex of antennomere VIII. Prothorax (including lateral tubercles) 1.14 times longer than wide; lateral tubercles distinctly visible, acute at apex. 

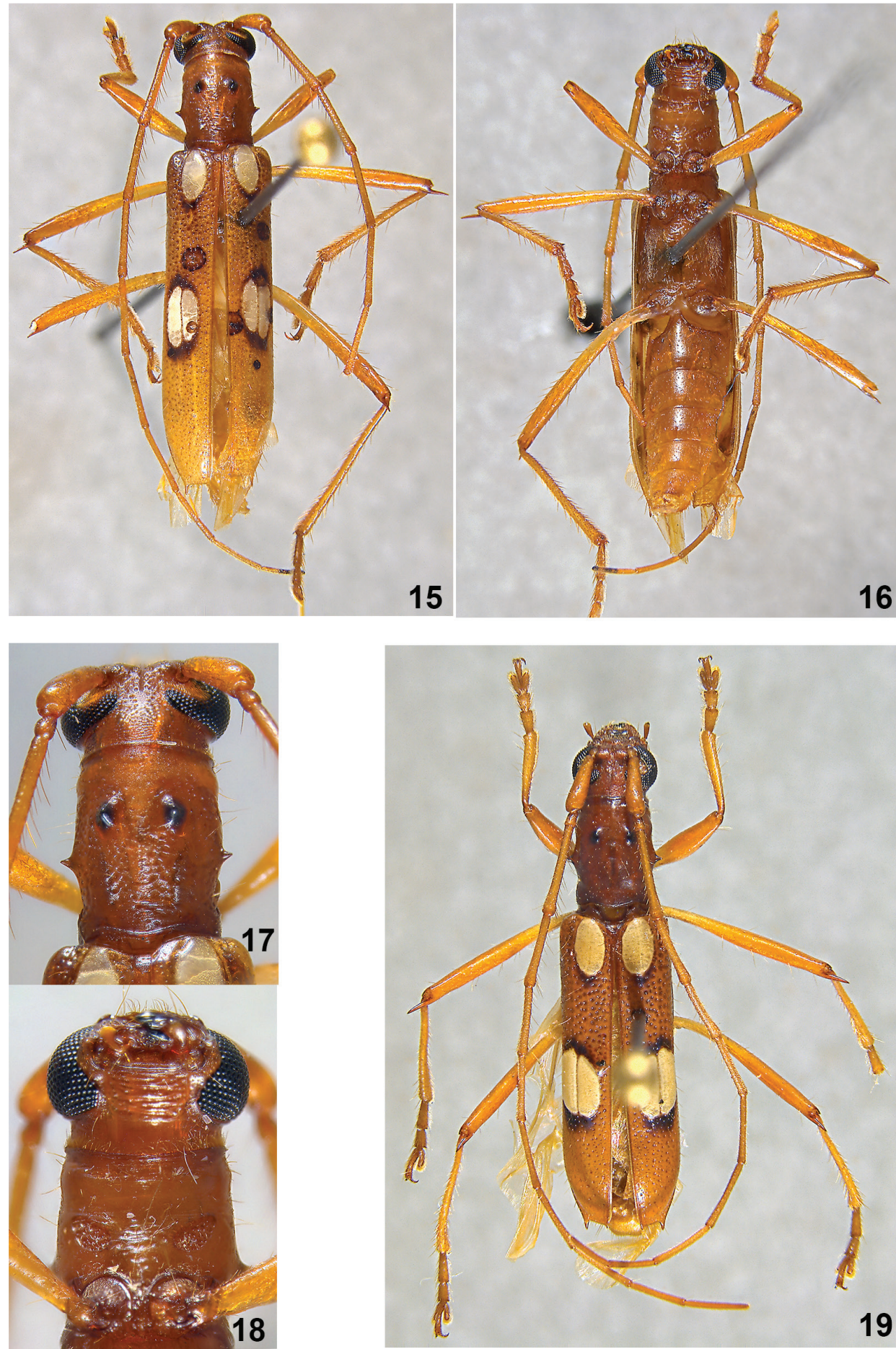

Figures 15-19. Beraba limpida Martins, 1997. I5-I8 male: I5 dorsal view 16 ventral view $\mathbf{7}$ detail of pronotum $\mathbf{I} \mathbf{8}$ detail of prosternum $\mathbf{1} \mathbf{9}$ female, dorsal view. 
Thorax. Surface of pronotum with coarse dense punctuation; with two anterior elevated tubercles rounded at apex. Prosternum smooth on central region, with long, erect setae and a few punctures, with evident sexual punctation at lateral sides concentrated on subrounded areas (Figs 16, 18). Coxae and mesoventral process covered with dense whitish pubescence. Meso- and metaventrite with long erect setae and covered with dense whitish pubescence laterally. Femora and tibiae fine and long; apex of meso- and meta-femora with long inner spine.

Elytra about 3.5 times longer than prothorax; surface with dense, coarse punctures basally, finer and shallow toward apex. Each elytron with three eburneous callosities: one basal, elliptical; two posterior, slightly elongated, inner one slightly smaller than external one, not distinctly separated from each other. Posteroexternal callosity about one fifth of elytral length, starting ahead of internal one. Elytral costae absent. Apex of elytra with external long spine, about 0.8 times as long as the pedicel and with acute sutural projection.

Measurements. Male. Total length, 10.3; prothorax length, 2.1; prothorax width at its widest point, 1.9; elytral length, 7.3; humeral width, 2.0.

Discussion. Beraba limpida was described by Martins (1997) based on a single female specimen, and until now the male remained unknown. Among the known males of Beraba, just one species has sexual punctation, B. piriana Martins, 1997. The sexual punctation in this species covers the entire prosternum and extends to the lateral region of the pronotum. Herein, we report sexual punctation for the first time in other two species of Beraba: B. limpida and B. angeli sp. n. In those species, the sexual punctation covers the entire surface of the pronotum, and is concentrated in subrounded areas on sides of the prosternum (Figs 9, 11, 16, 18).

One specimen of Beraba tate Galileo \& Martins, 2010 was illustrated by Galileo et al. (2008) as being B. limpida. Later, Galileo and Martins (2010) recognized that this specimen belongs to a new species, and described it as B. tate. However, Galileo et al. (2008) remains wrongly listed in the references on B. limpida (see Monné 2018; Tavakilian and Chevillotte 2018). In order to correct this error, we point out that this reference should appear on $B$. tate.

\section{New geographical records}

\section{Beraba inermis Martins \& Galileo, 2002}

Geographical distribution. Colombia (Cundinamarca, Valle del Cauca). New department records are added: Amazonas and Bolívar (Colombia).

Specimens examined. Colombia, Amazonas: Leticia, 1 female, 1.V.2001, Sarmiento Paula coll., Andes-E1162 (ANDES-E); Bolívar: San Jacinto (Reserva La Flecha, $09^{\circ} 51^{\prime} 12.4^{\prime \prime} \mathrm{N}, 75^{\circ} 10^{\prime} 41.4^{\prime \prime W}$, tropical dry forest), 1 male, 27.IV.2017, I. Mendoza coll., light trap (UARC). 


\section{Beraba iuba Martins, 1997}

Geographical distribution. Ecuador. A new country record from Colombia (Bolívar) is added.

Specimen examined. Colombia, Bolívar: San Jacinto (Reserva La Flecha, $09^{\circ} 51^{\prime} 12.4^{\prime \prime N}, 75^{\circ} 10^{\prime} 41.4 " \mathrm{~W}$, tropical dry forest), 1 male, 27.IV.2017, I. Mendoza coll., light trap (UARC).

\section{Beraba limpida Martins, 1997}

Geographical distribution. Venezuela. A new country record from Colombia (Bolívar) is added.

Specimens examined. Colombia, Bolívar: San Jacinto (Reserva La Flecha, $09^{\circ} 51^{\prime} 12.4^{\prime \prime} \mathrm{N}, 75^{\circ} 10^{\prime} 41.4 " \mathrm{~W}$, tropical dry forest), 1 male, 1 female, 27.IV.2017, I. Mendoza coll., light trap (UARC).

\section{Beraba marica Galileo \& Martins, 2000}

Geographical distribution. Colombia (Bolívar). New department records are added: Atlántico, Magdalena and Santander (Colombia).

Specimen examined. Colombia, Atlántico: Usiacurí; (Reserva Campesina La Montaña, $10^{\circ} 46^{\prime} 2.6^{\prime \prime} \mathrm{N}, 75^{\circ} 0.2^{\prime} 34^{\prime \prime} \mathrm{W}$, tropical dry forest), 1 male, 14.V.2018, K. García

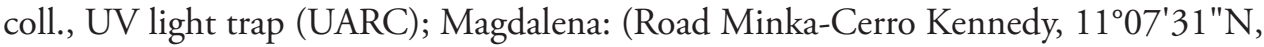
7406'07"W, 1000 m), 1 female, 7-8.VI.2018, V. Sinyaev coll. (MZSP); Santander: Carmen de Churucí (Vereda La Belleza, Finca Santiago, Campamento, 06 $34^{\prime} 49.5^{\prime N}$, 73³4'15.1"W, 801 m, Bosque húmedo tropical), 18-25.II.2018, Neita, J. C. coll., "captura manual", CAS-00039 (IAVH).

\section{Beraba piriana Martins, 1997}

Geographical distribution. Panama, Colombia (Magdalena). New department records are added: Atlántico and Bolívar (Colombia).

Specimens examined. Colombia, Atlántico: Baranoa (1047'56.04"N, 7455'19.56"W), 2 males, 4.IV.2017, I. Mendoza coll., manual capture (UARC); Usiacurí; (Reserva Campesina La Montaña, $10^{\circ} 46^{\prime} 2.6^{\prime \prime} \mathrm{N}, 75^{\circ} 0.2^{\prime} 34^{\prime \prime W}$, tropical dry forest), 1 male, 1 female, 12.V.2018, K. García coll., white light trap (UARC); 1 female, 12.V.2018, K. García coll., UV light trap (MZSP); 1 female, 12.V.2018, K. García coll., manual capture (UARC); Bolívar: San Jacinto (Reserva La Flecha, 0951'12.4"N, $75^{\circ} 10^{\prime} 41.4$ "W, tropical dry forest), 2 males, 1 female, 16.IV.2018, K. García col., 
UV light trap (UARC); Bolívar: San Jacinto (Reserva La Flecha, 0951'12.4"N, $75^{\circ} 10^{\prime} 41.4^{\prime \prime} \mathrm{W}$, tropical dry forest), 1 male, 27.IV.2017, I. Mendoza coll., light trap (UARC); Bolívar: San Jacinto (Reserva La Flecha, 0951'12.4"N, 75¹0'41.4"W, tropical dry forest), 1 female, 6.VI.2016, J. Barraza coll., van someren-rydon (UARC).

\section{Eburodacrys asperula Bates, 1880}

Geographical distribution. Honduras, Mexico (Veracruz), Guatemala, Costa Rica, Panama, Venezuela. A new country record from Colombia (Magdalena) is added.

Specimens examined. Colombia, Magdalena (Road Minka-Cerro Kennedy, $\left.11^{\circ} 07^{\prime} 31^{\prime \prime N}, 74^{\circ} 06^{\prime} 07^{\prime \prime W}, 1000 \mathrm{~m}\right), 1$ male, 1 female, 7-8.VI.2018, V. Sinyaev coll. (MZSP).

\section{Eburodacrys callixantha Bates, 1872}

Geographical distribution. Honduras, Mexico (Jalisco, Oaxaca), Nicaragua, Panama, Venezuela. A new country record from Colombia (Magdalena) is added.

Specimen examined. Colombia, Magdalena: San Pablo; (La Clarita, 1052'37.3"N, 7408'03.9"W), 3 males, 28.V.2017, I. Mendoza and L. Martinez coll., light trap (UARC).

\section{Eburodacrys coalescens Bates, 1884}

Geographical distribution. Mexico, Guatemala, Honduras, Nicaragua, Costa Rica, Panama. A new country record from Colombia (Atlántico) is added.

Specimens examined. Colombia, Atlántico: Usiacurí; (Reserva Campesina La Montaña, $10^{\circ} 46^{\prime} 2.6^{\prime \prime} \mathrm{N}, 75^{\circ} 0.2^{\prime} 34^{\prime \prime} \mathrm{W}$, tropical dry forest), 2 females, 12.V.2018, K. García coll., white light trap (MZSP, UARC).

\section{Eburodacrys havanensis Chevrolat, 1862}

Geographical distribution. Cuba, Mexico, Nicaragua, Costa Rica, Panama, Colombia (Antioquia, Cundinamarca, Huila, Meta, Putumayo, Quindío, Santander, Tolima), Venezuela, Bolivia (Beni, Santa Cruz), Brazil (Mato Grosso, Mato Grosso do Sul, Goiás, Distrito Federal, Maranhão, Piauí, Pernambuco, Bahia, Minas Gerais, Espírito Santo, Rio de Janeiro, São Paulo, Paraná, Santa Catarina, Rio Grande do Sul), Paraguay. A new department record from Bolívar (Colombia) is added.

Specimens examined. Colombia, Bolívar: San Jacinto (Reserva La Flecha, 0951'12.4"N, 75¹0'41.4"W, tropical dry forest), 1 male, 13.IV.2018, K. García coll., white light trap (UARC); 1 male, 27.IV.2017, I. Mendoza coll., light trap (UARC). 


\section{Eburodacrys moruna Martins, 1997}

Geographical distribution. Colombia (Magdalena). New department records are added: Atlántico and Bolívar (Colombia).

Specimens examined. Colombia, Atlántico: Usiacurí (Reserva Campesina la Montańa, $10^{\circ} 46^{\prime} 2.6^{\prime \prime} \mathrm{N}, 75^{\circ} 0.2^{\prime} 34^{\prime \prime} \mathrm{W}$, tropical dry forest), 1 female, 14.VI.2018, J. Sarmiento coll., pitfall (UARC). Bolívar: San Jacinto (Reserva La Flecha, 0951'12.4"N, $75^{\circ} 10^{\prime} 41.4 \mathrm{~W}$, tropical dry forest), 1 female, 27.IV.2017, I. Mendoza coll., light trap (UARC).

\section{Eburodacrys santossilvai Botero, 2017}

Geographical distribution. Venezuela. A new country record from Colombia (Atlántico, Bolívar) is added.

Specimens examined. Colombia, Atlántico: Usiacurí; (Reserva Campesina La Montaña, 10 $46^{\prime} 2.6^{\prime \prime} \mathrm{N}, 75^{\circ} 0.2^{\prime} 34^{\prime \prime} \mathrm{O}$, tropical dry forest), 1 female, 14.V.2018, K. García coll., UV light trap (UARC); Bolívar: San Jacinto (Reserva La Flecha, $09^{\circ} 51^{\prime} 12.4^{\prime \prime N}, 75^{\circ} 10^{\prime} 41.4 " \mathrm{~W}$, tropical dry forest), 1 female, 16.III.2018, K. García coll., UV light trap (UARC); 2 males, 27.IV.2017, I. Mendoza coll., light trap (UARC).

\section{Eburodacrys triocellata (Stal, 1857)}

Geographical distribution. Mexico, Guatemala, Nicaragua, Costa Rica, Panama, Colombia (Antioquia, Arauca, Boyacá, Caldas, Cesar, Cundinamarca, Magdalena, Meta, Tolima, Valle del Cauca), Venezuela. New department records are added: Amazonas, Atlántico and Bolívar (Colombia).

Specimen examined. Colombia, Amazonas: Leticia, female, 1.V.2001, Daniel Matute coll., Andes-E384 (ANDES-E); Atlántico: Usiacurí; (Reserva Campesina La Montaña, $10^{\circ} 46^{\prime} 2.6^{\prime \prime} \mathrm{N}, 75^{\circ} 0.2^{\prime} 34^{\prime \prime} \mathrm{W}$, tropical dry forest), 1 female, 15.II.2018, K. García coll., white light trap (UARC); 1 female, 12.V.2018, K. García coll., manual capture (UARC); 2 females, 12.V.2018, K. García coll., white light trap (UARC); Bolívar: San Jacinto (Reserva La Flecha, 09²1'12.4"N, 75¹0'41.4"W, tropical dry forest), 1 male, 1 female, 16.IV.2018, K. García coll., UV light trap (UARC); 2 male, 5 females, 27.IV.2017, I. Mendoza coll., light trap (UARC).

\section{Acknowledgments}

We are grateful to the members of the "NEOPTERA" team, especially those who helped in the sampling; to José Sarmiento, Jeniffer Meriño, Ivan Mendoza, Leonel Martínez and Jesus Barraza for collecting some of the material examined; to Larry Bezark for the 
photographs of $B$. iuba, reviewing the English text and providing helpful comments on the manuscript; to all the curators of collections for loans of specimens; and to Antonio Santos-Silva and Francesco Vitali for their helpful comments and corrections of the manuscript. The second author thanks to "Fundação de Amparo à Pesquisa do Estado de São Paulo" (FAPESP) for a postdoctoral fellowship (process number 2017/17898-0).

\section{References}

Bates H (1872) On the longicorn Coleoptera of Chontales, Nicaragua. The transactions of the entomological society of London 1872: 163-238. https://doi.org/10.1111/j.1365-2311.1872. tb01888.x

Bates H (1884) Insecta, Coleoptera. Supplement to longicornia. Biologia centrali-americana 5: 225-248.

Botero JP (2015) Three new species, a lectotype designation and taxonomic and geographic notes in Eburiini (Coleoptera, Cerambycidae, Cerambycinae). European Journal of Taxonomy 148: 1-22. https://doi.org/10.5852/ejt.2015.148

Botero JP, Monné ML (2018) Cladistic analysis of the tribe Eburiini Blanchard, 1945 and revalidation of the tribe Dychophyiini Gistel, 1848 (Coleoptera: Cerambycidae). Zoological Journal of the Linnean Society 2018: 1-28. https://doi.org/10.1093/zoolinnean/zly065

Chevrolat L (1862) Coléoptères de l'Ile de Cuba. Notes, synonymies et descriptions d'espèces nouvelles. Familles des Cérambycides et des Parandrides. Annales de la Société Entomologique de France (4)2: 245-280.

Galileo M, Martins U (2000) Novos táxons e nova combinação em Cerambycinae (Coleoptera) sul-americanos. Papéis Avulsos de Zoologia 41(10): 155-172.

Galileo MHM, Martins UR, Moysés E (2008) Cerambycidae Sul-americanos (Coleoptera) Suplemento 2. Museu de Zoologia. Universidade de São Paulo, São Paulo, 127 pp.

Galileo MHM, Martins UR (2010) Novos táxons em Elaphidionini e Eburiini (Cerambycidae, Cerambycinae). Revista Brasileira de Entomologia, Curitiba 54(3): 367-371. https://doi. org/10.1590/S0085-56262010000300004

Martínez C (2000) Escarabajos longicornios (Coleoptera: Cerambycidae) de Colombia. Biota Colombiana 1(1): 76-105.

Martins U (1997) Contribuições para uma revisão das espécies sul-americanas da Tribo Eburiini (Coleoptera, Cerambycidae). Revista Brasileira de Entomologia 41(1): 57-83.

Martins U, Galileo M (2002) Cerambycidae (Coleoptera) da Colômbia. I. Eburiini (Cerambycinae). Iheringia (Série Zoologia) 92(4): 5-10. https://doi.org/10.1590/S007347212002000400001

Monné MA (2018) Catalogue of the Cerambycidae (Coleoptera) of the Neotropical region. Part I. Subfamily Cerambycinae.

Stal C (1857) Några nya arter af Longicornia. Öfversigt af Kongliga Svenska Vetenskaps-Akademiens Förhandlingar 14: 63.

Tavakilian G, Chevillotte H (2018) Titan: base de données internationales sur les Cerambycidae ou Longicornes. Version 3.0. http://titan.gbif.fr/ [Accessed October 2018] 